\section{Performance of Paper Mulches Using a Mechanical Plastic Layer and Water Wheel Transplanter for the Production of Summer Squash}

\author{
Timothy Coolong ${ }^{1}$
}

\begin{abstract}
AdDITIONAL INDEX WORDs. biodegradable, Cucurbita pepo, polyethylene mulch
Summary. Polyethylene mulches are widely used in vegetable production.

Advantages include improving yields, controlling weeds, and enhancing quality. However, the removal and disposal of plastic mulch used for vegetable production represents a significant financial cost for farmers and can be detrimental to the environment. A study was conducted in Fall 2007 and Spring 2008 evaluating the performance of paper mulches for the production of summer squash (Cucurbita pepo ssp. ovifera) 'Conqueror III'. Four paper mulches, 50-1b kraft paper, 50-1b polyethylene-coated kraft paper, 40-lb white butcher paper, and 30-lb waxed paper were compared with 1-mil black polyethylene mulch, bare-ground hand-weeded, and bare-ground nonweeded treatments. Mulches were placed using a traditional plastic mulch layer and seedlings were transplanted using a water wheel transplanter. Crop yield and quality, weed biomass, soil temperatures under the mulch (Spring 2008 only), and mulch degradation were evaluated. Most paper mulches were able to be placed with a mulch layer, but were not well suited for use with a water wheel transplanter. In Fall 2007, butcher paper and polyethylene-coated kraft paper controlled weeds as well as black plastic mulch. However, in Spring 2008, black plastic mulch provided superior weed control compared with other mulches. Yields among waxed, butcher, and polyethylene-coated kraft papers were similar to black plastic mulch in 2007 , though yields in paper mulch plots were significantly less than plastic mulch in Spring 2008. The results of this study suggest that although paper mulches can be effective, cropping conditions and the environment will influence effectiveness.
\end{abstract}

$\mathrm{P}$ olyethylene was developed as a film in 1938 and was produced on a commercial scale in 1939 (Lamont, 1993). The use of polyethylene plastic first as a cover for greenhouse structures and later as a mulch film for the production of vegetables was pioneered in the 1950s by the late Dr. Emery Emmert at the University of Kentucky (Emmert, 1957). Commercially, plastic mulches have been used for the production of vegetables since the 1960s (Lamont, 2005). Plastic mulches are an important management tool for modern vegetable production systems. Polyethylene mulches are used for vegetable production because they improve earliness and crop yields through increased soil temperatures, reduced evaporation of soil water, reduced weed pressure, and improved produce quality (Lamont, 1993, 2005).

Assistant Professor, Department of Horticulture, N-318 Agricultural Sciences North, University of Kentucky, Lexington, KY 40546-0091

${ }^{1}$ Corresponding author. E-mail: timcoolong@uky.edu.
There are some disadvantages to plastic mulches. Disposal options are limited. Plastic mulches are typically landfilled, burned, or disposed of illegally. Although recycling may be an option, polyethylene mulches used in vegetable production are contaminated with too much dirt and debris to be recycled directly from the field (Hemphill, 1993). Polyethylene mulches contain nearly as much potential energy per unit weight as oil $(20,000 \mathrm{Btu} / \mathrm{lb})$ and could be incinerated to produce heat or electricity
(American Society for Plasticulture, 1991; Hemphill, 1993; Lamont, 2005). However, most power plants and incinerators are not designed to burn dirt- and debris-covered plastic, and operators are reluctant to make attempts to do so (J. Wilhoit, personal communication). Researchers at The Pennsylvania State University have tested "fuel nuggets" made of compressed plastic mulches to be used as a supplemental fuel in coal fired burners (Garthe et al., 2003). An alternative solution for reducing waste from polyethylene mulches is to develop photodegradable or biodegradable mulches (Sorkin, 2006).

Photodegradable mulch films have been tested intermittently for more than 20 years (Hemphill, 1993). Results have been variable, with many films degrading prematurely (Greer and Dole, 2003; Halley et al., 2001). Furthermore, the ability of photodegradable mulches, which are manufactured with petroleum-based ingredients, to degrade into carbon dioxide and water has been questioned (Zhang et al., 2008).

Paper-based mulches have been used in agriculture since 1914, when paper was used to reduce weed pressure in sugar cane (Saccharum officinarum) fields (Smith, 1931). Asphalt-impregnated paper mulches were successfully used in pineapple (Ananas comosus) production in the 1920s in Hawaii, increasing quality and yields (Smith, 1931). Paper mulches have since been evaluated with varying results. Newspaper mulches represent an available and cost-effective resource and have been frequently trialed (Shogren, 2000). Munn (1992) reported increased yields with shredded newspaper compared with straw mulches in corn (Zea mays) and soybean (Glycine max). Recently,

\begin{tabular}{llll}
\hline $\begin{array}{l}\text { Units } \\
\begin{array}{l}\text { To convert U.S. to SI, } \\
\text { multiply by }\end{array}\end{array}$ & U.S. unit & SI unit & $\begin{array}{l}\text { To convert SI to U.S., } \\
\text { multiply by }\end{array}$ \\
\hline 1.0551 & $\mathrm{Btu}$ & $\mathrm{kJ}$ & 0.9478 \\
1 & $\mathrm{cbar}$ & $\mathrm{kPa}$ & 1 \\
0.3048 & $\mathrm{ft}$ & $\mathrm{m}$ & 3.2808 \\
3.7854 & $\mathrm{gal}$ & $\mathrm{L}$ & 0.2642 \\
2.54 & inch(es) & $\mathrm{cm}$ & 0.3937 \\
6.4516 & inch & $\mathrm{cm}^{2}$ & 0.1550 \\
0.4536 & $\mathrm{lb}$ & $\mathrm{kg}$ & 2.2046 \\
1.1209 & $\mathrm{lb} / \mathrm{acre}$ & $\mathrm{kg} \cdot h \mathrm{~h}^{-1}$ & 0.8922 \\
25.4 & $\mathrm{mil}$ & $\mu \mathrm{m}$ & 0.0394 \\
28.3495 & $\mathrm{oz}$ & $\mathrm{g}$ & 0.0353 \\
$\left({ }^{\circ} \mathrm{F}-32\right) \div 1.8$ & ${ }^{\circ} \mathrm{F}$ & ${ }^{\circ} \mathrm{C}$ & $\left(1.8 \times{ }^{\circ} \mathrm{C}\right)+32$
\end{tabular}


Sanchez et al. (2008) reported success when using shredded newspapers as a weed-suppressing mulch in organic high-tunnel cucumber ( $\mathrm{Cucu}$ mis sativus) production. However, some paper mulches deteriorate rapidly under field conditions, reducing their effectiveness (Shogren, 2000). Several trials have used paper mulches with polyethylene, wax, or vegetable oil coatings used to slow degradation of mulches in the field (Miles et al., 2003; Shogren, 1999; Shogren and David, 2006; Vandenberg and Tiessen, 1972).

Growers interested in using paper mulch on a larger scale may want to lay mulch and drip irrigation tape with a conventional plastic layer and plant using a water wheel transplanter. Miles et al. (2006) used traditional mulch laying equipment, though hand transplanted, to test the performance of several starchand paper-based mulches for organically managed lettuce (Lactuca sativa), broccoli (Brassica oleracea var. italica), bell pepper (Capsicum annuum), and watermelon (Citrullus lanatus) in the Pacific northwestern United States with variable results. In that trial, plastic-based mulches generally outperformed paper mulches; however, some of the plastic-based biodegradable products took longer to degrade than expected. Performance of paper mulches is likely to vary according to production region and management strategy. This trial was conducted to evaluate the performance of four readily obtainable papers compared with traditional black plastic with a short, warm-season crop (yellow squash) in the midsouthern United States using conventional plastic laying equipment and a water wheel transplanter for two growing seasons.

\section{Materials and methods}

Trials were conducted in Fall 2007 and Spring 2008 on the University of Kentucky Horticulture Research Farm in Lexington (lat. $37^{\circ} 58^{\prime} \mathrm{N}$, long. $\left.84^{\circ} 32^{\prime} \mathrm{W}\right)$. Soils on the farm are a Maury silt loam, with a $\mathrm{pH}$ of 6.5 to 6.8 . The following mulches were applied immediately before planting: 1-mil embossed black polyethylene mulch (Pliant Corp., Schaumburg, IL), 40-lb white butcher paper, 50-lb brown kraft paper, 30$\mathrm{lb}$ brown waxed paper, and $50-\mathrm{lb}$ kraft paper coated with a 10-lb polyethylene film facing the ground (Uline, Chicago). All mulches were obtained as 36-inch-wide rolls and were set on flat beds in the field using a mechanical mulch layer. Coulters mounted on the rear of the mulch layer pushed soil over the edges of the mulches, holding them tight to the soil surface. Two additional treatments were evaluated: bare ground with hand weeding and bare ground without hand weeding.

Four-week-old transplants of 'Conqueror III' yellow summer squash were greenhouse grown in 128-cell trays and transplanted into fields using a water wheel transplanter on 10 Aug. 2007 and 25 Apr. 2008. Treatment plots each consisted of a single row $30 \mathrm{ft}$ in length, containing 20 plants on 18-inch in-row spacing. Rows were spaced on 6-ft centers in the field. Single border rows with plants grown on black plastic mulch surrounded the entire field. Drip irrigation $[0.45 \mathrm{gal} / \mathrm{min}$ per $100 \mathrm{ft}$ (Aqua-Traxx; Toro, El Cajon, CA)] was used and plots were irrigated when soil moisture, measured as soil water tension, reached 35 cbar as determined by tensiometers placed at a depth of 12 inches in plots located in the center of the field used for the experiment. Treatments were arranged in a randomized complete block design with four replications. With the exception of weed management strategies, plants were grown according to University of Kentucky Cooperative Extension recommendations for summer squash (Bessin et al., 2007). For weed control, plots were cultivated and stale seed-bedded for 1 week before planting. No herbicide was applied in-row. Areas between rows were cultivated twice following transplant, and trifluralin (Treflan; Dow AgroSciences, Indianapolis) was incorporated according to labeled instructions for weed control. For the hand-weeded treatment, plots were weeded weekly by hand beginning 1 week after transplant.

Plants were first harvested on 4 Sept. 2007 and 6 June 2008. Harvests continued two to three times weekly until 19 Oct. 2007 and 2 July 2008 for the fall and spring plantings, respectively. Fruit were graded as culls, No. 1, and No. 2, according to U.S. Department of Agriculture (USDA) standards at each harvest (USDA, 1984). At the completion of the study, all aboveground growth from weeds located in a 6.5 -ft section in the center of each plot, measuring the entire width of a plot $(\approx 2 \mathrm{ft})$, was harvested and dried in an oven at $75{ }^{\circ} \mathrm{C}$ for $\mathrm{l}$ week to obtain weed biomass.

At transplanting, $\approx 22$-inch ${ }^{2}$ pieces of each type of paper mulch were placed in a nylon mesh onion bag and buried at a depth of $\approx 6$ inches in each plot. At the completion of the study, bags were removed from the plots and mulch degradation was visually evaluated. Visual observations were also conducted for mulches on the surface of the soil. Temperature probes, three per treatment (Watchdog 125; Spectrum Technologies, Plainfield, IL) were placed at a depth of 3 inches in the center of plots and soil temperatures were recorded every 30 min to determine the effects of the treatments on soil temperatures in Spring 2008. Soil temperature was not measured in Fall 2007. Our intent was to compare the effects of the paper mulches to traditional black plastic mulches for soil-warming characteristics.

All data were subjected to the GLM procedure testing for significance of treatment effects using SAS statistical software (version 9.1; SAS Institute, Cary, NC). Mean separations were performed using the Duncan's multiple range test for significance, with $P=0.05$. Covariance analysis was also conducted using weed biomass as a covariate to determine the treatment differences among mulch treatments.

\section{Results}

Crop YIELD. Mulch type significantly affected total marketable yield, and yields of U.S. No. 1 and No. 2 squash fruit (Table 1). In Fall 2007, total marketable yields of squash did not differ significantly among plants grown on black plastic, polyethylenecoated kraft paper, waxed paper, and butcher paper mulches. All had yields greater than $24,000 \mathrm{~kg} \cdot \mathrm{ha}^{-1}$. The total marketable yields for plants grown on the bare ground handweeded and bare ground nonweeded treatments were significantly less than the plants grown on black plastic mulch. In Fall 2007, plants grown on black plastic, polyethylene-coated kraft paper, waxed paper, and butcher paper mulches had statistically similar yields for U.S. No. 1 squash. Plants 


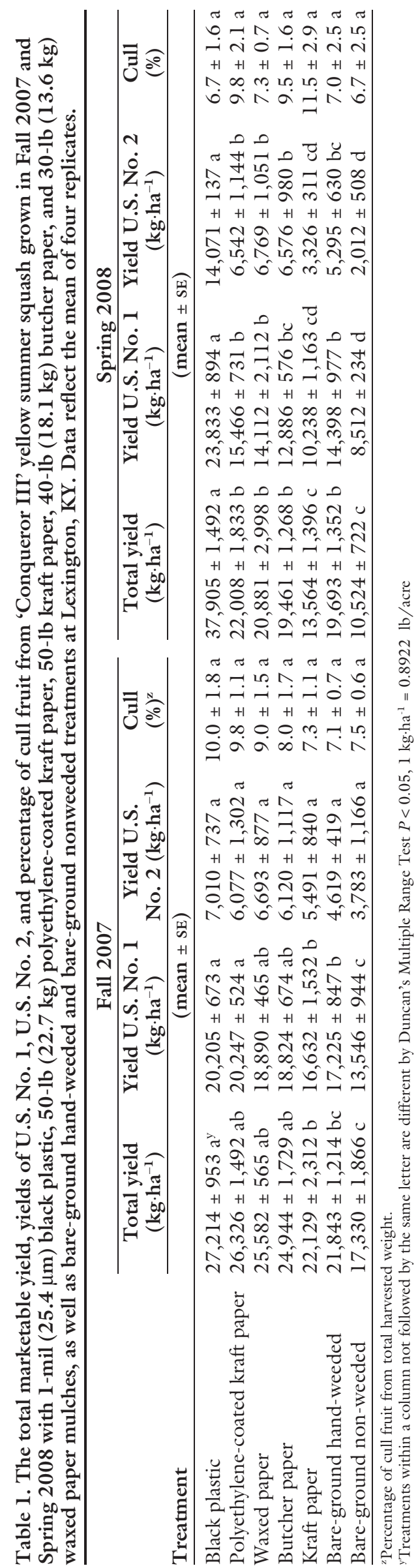

grown on kraft paper mulch and in the bare ground hand-weeded treatment had similar yields and were not significantly different from those grown on waxed and butcher paper mulches. However, yields of U.S. No. l squash grown with the kraft paper mulch and bare ground hand-weeded treatments were significantly less than those plants grown on black plastic and polyethylene-coated kraft paper mulches. Yields of U.S. No. 1 squash were significantly lower in the bare ground non-weeded treatment than all other treatments in Fall 2007. Yields of U.S. No. 2 squash fruit were not significantly different among any treatments in Fall 2007. Yields of U.S. No. 2 squash ranged from over $7000 \mathrm{~kg} \cdot \mathrm{ha}^{-1}$ for plants grown on black plastic mulches to less than $4000 \mathrm{~kg} \cdot \mathrm{ha}^{-1}$ for plants grown in bare ground nonweeded treatment. The percentage cull fruits, based on total harvested weight, were not significantly different in any of the treatments in Fall 2007.

In Spring 2008, plants grown on the black plastic mulch had the highest total marketable yield, averaging nearly 38,000 $\mathrm{kg} \cdot \mathrm{ha}^{-1}$ (Table 1). Plants grown on black plastic mulch had significantly greater total marketable yields than any other treatment. Total marketable yields for plants grown in the bare ground handweeded treatments, as well as on the polyethylene-coated kraft, waxed, and butcher paper mulches, did not differ significantly, and were all greater than $19,000 \mathrm{~kg} \cdot \mathrm{ha}^{-1}$. Plants grown on kraft paper mulch and in the bare ground nonweeded treatment had total marketable yields that were less than all other treatments. Yields of U.S. No. 1 fruit followed a similar pattern as total marketable yield in Spring 2008. Yields of U.S. No.l fruit were highest for plants grown on black plastic mulch. Yields of U.S. No. 1 fruit were not statistically different among plants grown on the polyethylene-coated kraft paper, waxed paper, butcher paper, and bare ground hand-weeded treatments. Yields of U.S. No. 1 fruit were lowest in the in the kraft paper mulch and bare ground nonweeded treatments. In Spring 2008, yields of U.S. No 2 fruit were significantly greater in the black plastic mulch than any other treatment. Yields of U.S. No. 2 fruit were not statistically different among 
the polyethylene-coated kraft paper, waxed paper, butcher paper, and bare ground hand-weeded treatments in Spring 2008. In addition, in Spring 2008, yields U.S. No. 2 fruit were lowest on the bare ground nonweeded control treatment, which was significantly less than all other treatments, except for the kraft paper mulch. There were no significant differences in the percentage of cull fruit in any treatments in Spring 2008. Culls, as a percentage of total harvested weight, ranged from $6.7 \%$ to $11.5 \%$.

WeED CONTROL. Butcher paper, polyethylene-coated kraft paper, black plastic, and bare ground hand-weeded treatments were not statistically different with respect to weed biomass in the Fall 2007 trial (Table 2). The kraft paper and waxed paper mulches did differ significantly from the black plastic mulch and bare ground handweeded treatments in 2007 . The bare ground nonweeded treatment had the greatest level of weed biomass in Fall 2007.

Weed biomass was significantly different in the black plastic mulch and the bare ground hand-weeded treatments compared with all other treatments in Spring 2008 (Table 2). Weed biomass was not statistically different in the polyethylene-coated kraft, waxed, and butcher paper mulches in Spring 2008. Weed biomass measured in the bare ground nonweeded treatments was significantly greater than all other treatments in Spring 2008. There were no differences in the relative performance of the different paper mulch treatments for weed biomass in both seasons. No differences in the weed communities between mulch treatments were observed in either season.

SOIL TEMPERATURE. Black plastic mulch resulted in the greatest average soil temperature, $\approx 3.7^{\circ} \mathrm{F}$ greater than the bare ground hand-weeded

Table 2. Average dry weight of weed biomass from aboveground growth of weeds collected from $6.5 \mathrm{ft}(1.98 \mathrm{~m}) \times 2 \mathrm{ft}(0.61 \mathrm{~m})$ sections in the center of mulch plots containing 1 -mil $(25.4 \mu \mathrm{m})$ black plastic, $50-1 \mathrm{~b}(22.7 \mathrm{~kg})$ polyethylene-coated kraft paper, 50-lb kraft paper, 40-1b $(18.1 \mathrm{~kg})$ butcher paper, and $30-1 b(13.6 \mathrm{~kg})$ waxed paper mulches, as well as bare-ground hand-weeded and bare-ground nonweeded treatments in Fall 2007 and Spring 2008 at Lexington, KY.

\begin{tabular}{lcc}
\hline Treatment & $\begin{array}{c}\text { Fall 2007 } \\
\text { Weed biomass } \\
{[\text { mean } \pm \text { SE }(\mathrm{g})]^{\mathrm{z}}}\end{array}$ & $\begin{array}{c}\text { Spring 2008 } \\
\text { Weed biomass } \\
{[\text { mean } \pm \text { SE }(\mathrm{g})]}\end{array}$ \\
\hline Bare-ground nonweeded & $511 \pm 77 \mathrm{a}^{\mathrm{y}}$ & $1,603 \pm 70 \mathrm{a}$ \\
Kraft paper & $256 \pm 61 \mathrm{~b}$ & $1,146 \pm 117 \mathrm{~b}$ \\
Waxed paper & $157 \pm 41 \mathrm{bc}$ & $1,005 \pm 129 \mathrm{bc}$ \\
Butcher paper & $110 \pm 35 \mathrm{~cd}$ & $803 \pm 61 \mathrm{~cd}$ \\
Polyethylene-coated kraft paper & $57 \pm 14 \mathrm{~cd}$ & $713 \pm 39 \mathrm{~d}$ \\
Black plastic & $28 \pm 20 \mathrm{~d}$ & $121 \pm 25 \mathrm{e}$ \\
Bare-ground hand-weeded & $19 \pm 3.5 \mathrm{~d}$ & $103 \pm 24 \mathrm{e}$ \\
\hline
\end{tabular}

${ }^{2}$ Data reflect the mean of four replicate; $1 \mathrm{~g}=0.0353 \mathrm{oz}$

yTreatments not followed by the same letter are different by Duncan's multiple range test at $p<0.05$.

Table 3. Average soil temperatures at depth of 3 inches $(7.6 \mathrm{~cm})$ in mulch plots containing $1-\mathrm{mil}(25.4 \mu \mathrm{m})$ black plastic, $50-1 b(22.7 \mathrm{~kg})$ polyethylene-coated kraft paper, 50-1b kraft paper, 40-1b (18.1 kg) butcher paper, and 30-1b (13.6 kg) waxed paper mulches, as well as bare-ground hand-weeded treatments for the entire duration of the study, the first $14 \mathrm{~d}$, and the last $14 \mathrm{~d}$ in Spring 2008 at Lexington, KY.

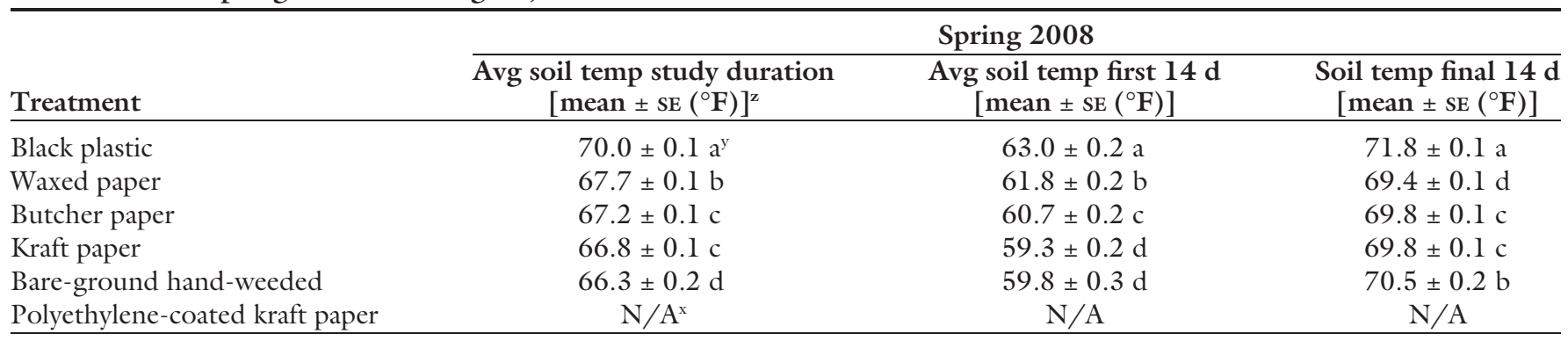

${ }^{2}$ Data reflect the mean of three replicates; $\left({ }^{\circ} \mathrm{F}-32\right) \div 1.8={ }^{\circ} \mathrm{C}$.

yTreatments within a column not followed by the same letter are different by Duncan's multiple range test at $P<0.05$.

${ }^{\mathrm{N}} \mathrm{N} / \mathrm{A}=$ not available. 
on the soil surface had some tearing, but remained relatively intact until the end of the study.

\section{Discussion}

If paper mulches are ever to be used on a large scale, they will have to be used in conjunction with mulchlaying equipment and perhaps mechanical transplanters. Laying the paper mulches was generally slower than laying the black plastic mulch. Though some of the paper mulches were well adapted to placement on flat beds with a mulch layer, the waxed paper mulch, which at $30 \mathrm{lb}$ had the lowest basis weight, tore easily and was difficult to place in the field. It should also be noted that due to the inelasticity of the paper, none of the paper mulches were able to be used in raised bed production. Transplanting with the water wheel setter provided mixed results. Although the black plastic and polyethylene-coated kraft paper mulches performed well with the water wheel transplanter, excess water caused the paper mulches to stick to the wheel, resulting in tearing, which allowed for weed growth. Of the paper-based mulches tested, the butcher paper, kraft paper, and polyethylene-coated kraft paper mulches were suitable to lay on a flat bed with a traditional plastic layer. However, only the polyethylene-coated kraft paper would be acceptable for use with a water wheel transplanter.

Commercially acceptable yields of summer squash in Kentucky are about $24,600 \mathrm{~kg} \cdot \mathrm{ha}^{-1}$ (Isaacs et al., 2004). In the Fall 2007 trial, the black plastic, polyethylene-coated kraft paper, and butcher paper treatments had average yields that exceeded this mark. In Spring 2008, only plants grown in black plastic mulch had yields exceeding average commercial yields for Kentucky, though plants grown on polyethylene-coated kraft paper did have yields greater than 22,000 $\mathrm{kg} \cdot \mathrm{ha}^{-1}$. There are several likely environmental factors that contributed to the treatment and seasonal differences in yield. Average air temperatures were higher in Fall $2007\left(74^{\circ} \mathrm{F}\right)$ than in Spring 2008 (67 $\left.{ }^{\circ} \mathrm{F}\right)$ (University of Kentucky Agricultural Weather Center, 2009). In addition, differences in weed pressure were observed among the treatments, which may have contributed to differences in yield.
To determine the effects of mulch treatment while accounting for weed pressure a covariance analysis, using weed biomass as a covariate in 2007 and 2008 was also conducted. When only mulch and the nonweeded bare ground treatments were considered (excluding hand-weeded control), there were no treatment differences observed in Fall $2007(P=0.206)$ or Spring 2008 ( $P=0.216)$ using weed biomass as a covariate. This suggests that weed pressure may be primarily responsible for yield differences among the mulches trialed. When bare ground hand-weeded treatments were added to the covariate analysis for Fall 2007 and Spring 2008, significant $(P<0.05)$ treatment effects were observed in both seasons. Yields in the bare ground hand-weeded treatments were significantly less than the black plastic mulch treatments in both seasons, despite having statistically similar levels of weed biomass. However, yields for the bare ground hand-weeded treatments were not significantly different from any of the paper mulch treatments in 2007 and 2008, with the exception of kraft paper in Spring 2008. The handweeded control treatment had lower yields than may be predicted based on weed biomass, suggesting that it may been an outlier. However, it is also possible that other factors such as soil temperature may have contributed to the yield differences between the black plastic mulch and bare ground hand-weeded treatment. Soil temperatures were highest under the black plastic mulch and lowest in the bare ground hand-weeded treatment for the duration of the study in Spring 2008. The soil temperature in the bare ground hand-weeded treatment did eventually increase and was the second highest average soil temperature for the final 2 weeks of the study in Spring 2008. However, the large differences in soil temperatures early on in the growing season may have contributed to the differences in yields for the black plastic mulch and bare ground hand-weeded treatments. Other environmental factors that could influence yield in the black plastic mulch and bare ground handweeded treatments that have been documented elsewhere, but not measured in this study include differences in evaporation and nutrient-leaching potential (Lamont, 1993, 2005).
For the bare ground nonweeded control, there was significantly more weed biomass ( $1603 \mathrm{~g}$ compared with $511 \mathrm{~g}$ ) in the spring than in fall. In fall, weed biomass measured in the butcher paper and polyethylenecoated kraft paper mulch plots was not significantly different from that of the black plastic mulch and the bare ground hand-weeded control treatments. However, in the Spring 2008 trial, the black plastic mulch and bare ground hand-weeded controls had significantly less weed biomass than the paper mulches. The reason for the difference in performance is likely two-fold. First, the fall trial was planted in late summer, after germination of spring weeds had occurred. Second, in Spring 2008, there were $20.9 \mathrm{~cm}$ of rainfall during the study, while in Fall 2007, there were $13.5 \mathrm{~cm}$ of rainfall (University of Kentucky Agricultural Weather Center, 2009). The higher rainfall in the spring may have led to a faster degradation of the paper mulches and greater weed growth compared with the fall, allowing for more weed penetration.

The best-performing paper-based mulch was the polyethylene-coated kraft paper. This mulch could be installed with a traditional flat-bed mulch layer and used in conjunction with a water wheel transplanter. This would make this mulch attractive to large-scale farming operations for which placing mulch and transplanting by hand would be impractical. However, the polyethylene coating, likely responsible for the enhanced performance of this mulch, is not biodegradable and would remain in the field after the growing season. Recently, Zhang et al. (2008) fieldtested biodegradable mulches made from kraft paper coated with a pregelatinized starch solution. In that study, no crops were grown, although the mulches performed well in the field. Mulches using the strength of paper combined with a biodegradable (not polyethylene) protective barrier to give the paper additional water resistance may be an option for the production of biodegradable mulches.

\section{Conclusions}

Paper mulches have been considered for use in fruit and vegetable production since the early 20th century (Smith, 1931). Although paper mulches were once widely used in 
vegetable crop production, their use waned as the many benefits of polyethylene mulches made them a more suitable choice for farmers. Recently, there has been interest in paper mulches because they are biodegradable, are manufactured from a renewable resource, and do not have to be removed from the field after harvest. Our results suggest that paper-based mulches have potential for some vegetable production systems.

Paper mulches clearly have limitations. Transportation costs for paper mulches, which are significantly heavier than polyethylene mulches, may limit their use. Paper mulches are also currently more expensive than polyethylene mulches. Rapid biodegradability, which is primarily responsible for the interest in paper mulch, is also a significant hurdle that must be overcome for paper mulches to be used. However, our results suggest that in some situations, paper mulches may provide a more sustainable alternative to traditional black plastic mulches. Results with the polyethylene-coated kraft paper suggest that efforts to combine paper with biodegradable films to create mulches may prove worthwhile.

\section{Literature cited}

American Society for Plasticulture. 1991. Agri-Plastics Rpt. 6:1-3.

Bessin, R., T. Coolong, R.T. Jones, J. Masabni, J. Strang, and K. Seebold. 2007. 2008-2009 Vegetable production guide for commercial growers. Univ. Kentucky Coop. Ext. Serv. Publ. ID-36.

Emmert, E.M. 1957. Black polyethylene for mulching vegetables. Proc. Amer. Soc. Hort. Sci. 69:464-469.

Garthe, J.W., B.G. Miller, R.S. Wasco, W.J. Lamont, and M.D. Orzolek. 2003.
Used agricultural plastic as a coal fuel supplement. Proc. 20th Natl. Agr. Plastics Congr. p. 53-57.

Greer, L. and J.M. Dole. 2003. Aluminum foil, aluminum-painted, plastic and degradable mulches increase yields and decrease insect-vectored diseases of vegetables. HortTechnology 13:276284.

Halley, P., R. Rutgers, S. Coombs, J. Kettels, J. Gralton, G. Christie, M. Jenkins, H. Beh, K. Griffin, R. Jayasekara, and G. Loneran. 2001. Developing biodegradable mulch films from starch-based polymers. Starch 53:362-367.

Hemphill, D.D. 1993. Agricultural plastics as solid waste: What are the options for disposal. HortTechnology 3:70-73.

Isaacs, S., S. Goode, R. Trimble, T. Woods, M. Ernst, J. Strang, B. Rowell, R.T. Jones, D. Spalding, and W. Dunwell. 2004. Vegetable and melon enterprise budgets v. 4. Univ. Kentucky Coop. Ext. Serv.

Lamont, W.J. 1993. Plastic mulches for production of vegetable crops. HortTechnology 3:33-39.

Lamont, W.J. 2005. Plastics: Modifying the microclimate for the production of vegetable crops. HortTechnology 15: $477-481$.

Miles, C., J. Reed, E. Klinger, L. Nelson, T. Smith, K. Kolker, and C. Cross. 2006. Alternatives to plastic mulch in vegetable production systems. 10 July 2008. <http://vegetables.wsu.edu/Mulch Report06.pdf>.

Miles, C., L. Garth, M. Sonde, and M. Nicholson. 2003. Searching for alternatives to plastic mulch. 10 Mar. 2009. $<$ http://vegetables.wsu.edu/Mulch Report03.pdf $>$.

Munn, D.A. 1992. Comparisons of shredded newspaper and wheat straw as crop mulches. HortTechnology 2:361366.
Sanchez, E., W.J. Lamont, and M.D. Orzolek. 2008. Newspaper mulches for suppressing weeds for organic hightunnel cucumber production. HortTechnology 18:154-157.

Shogren, R.L. 1999. Preparation and characterization of a biodegradable mulch: Paper coated with polymerized vegetable oils. J. Appl. Polym. Sci. 73: 2159-2167.

Shogren, R.L. 2000. Biodegradable mulches from renewable resources. J. Sustain. Agr. 16:33-47.

Shogren, R.L. and M. David. 2006. Biodegradable paper/polymerized vegetable oil mulches for tomato and pepper production. J. Appl. Hort. 8:12-14.

Smith, A. 1931. Effect of paper mulches on soil temperature, soil moisture, and yields of crops. Hilgardia 6:159-201.

Sorkin, L. 2006. New biodegradable mulch is cheaper than plastic when removal and disposal costs are also considered. Growing for Market May:8-10.

U.S. Department of Agriculture. 1984. United States standards for grades of summer squash. U.S. Dept. Agr., Washington, DC.

University of Kentucky Agricultural Weather Center. 2009. Lexington, Kentucky climate data. 23 Apr. 2009. <http://wwwagwx.ca.uky.edu/cgi-bin/ ky_clim_data_www.pl>.

Vandenberg, J. and H. Tiessen. 1972. Influence of wax-coated and polyethylene-coated paper mulch on growth and flowering of tomato. HortScience 7:464465.

Zhang, Y., J.H. Han, and G.N. Kim. 2008. Biodegradable mulch film made of starch-coated paper and its effectiveness on temperature and moisture content of soil. Commun. Soil Sci. Plant Anal. 39: 1026-1040. 